\title{
Development of Management Information System Reservations Using Simple Multi-Attribute Rating Technique (SMART) Based on Android Mobile Applications
}

\author{
Ahmad Habib, Ardy Januantoro, Okky Candra Srimarsono \\ Department of Informatics Engineering \\ Universitas 17 Agustus 1945 Surabaya, Indonesia \\ habib@untag-sby.ac.id
}

Abstract- In the information age, technology has become one of the things that are growing more rapidly, one of the technologies is the internet. From the use of the internet, it can also be used by sales that have Android mobile-based bread ordering information systems. By only using a cell phone, system users can order bread. This can be a tool in the special community in ordering bread. As with computers, mobile phones can also install a variety of software or software that they want. Besides, android phones can also be used for transactions. Like making a bread order transactions through an android phone. The stages that will be carried out by the author for the application development process include analysis and needs, application design, and application interface design, so that the application is made easy to use. The ordering system designed can make it easier for admin to view order details, check stock, manage customer data by using a database as a storage medium, and can also provide customers to buy stock of bakery goods available at these outlets to provide accurate information. The SMART method has been proven to be implemented in searches based on user preferences, and gives different results if the value of the criteria entered is different. However, conventional search methods are still provided in addition to searching for goods using the SMART Method.

Keywords - Management Information System, reservations, SMART, android Mobile Applications.

\section{INTRODUCTION}

In the information age, technology is developing rapidly, such as the use of RFID technology and SMS gateway[1], information system technology using the Odometer[2], segmentation system in the medical field[3], school financial information system[4], product marketing services[5]. Currently, one of these technologies that are in high demand is a mobile application-based system. In its application, mobile-based systems can be used in the business scope such as finding customer addresses[6], booking a room for UMKM activities[7], agenda reminder[8], malware detection[9], and used for membership activities of an organization by creating informative alumni data[10].

In this study, researchers implemented a mobile application that is used for ordering food. In previous research[11][12][13], food reference in the order selection process using alphabetical sorting and product upload date. This method is less effective because sometimes references do not match the customer's needs. A good decision support system as a customer reference, in this case, is very much needed. Many decision-making methods are widely used[14][15], One of them is the SMART method. Research using the SMART method has been used by many researchers before because the SMART method is quite effective in simplifying and accelerating the decision-making process by solving the problem into its parts[16]. Several previous studies used the SMART method to determine landfills[17], to promote employee promotions by determining the criteria for work experience, 
potential results, performance and attendance[18], selection of exemplary employees[19], business worthed[20], Building selection[21].

In this paper, the researcher uses a decision system based on the SMART method as a reference for ordering food to better suit customer needs. This study uses 4 criteria that will be used as a source of assessment, namely taste, price, and selling period. The SMART model was chosen because the SMART Model not only leads to logical results, it also allows decision-makers to visualize the effects of various criteria on the outcome[22].

\section{METHOD}

Data collection is done using interviews and observations. Researchers interviewed parties directly involved in the use of information technology. Then the researcher made observations with the parties directly involved in the use of information technology, the involvement of information technology in each transaction, and the parties involved in the transaction.

Simple Multi-Attribute Rating Technique (SMART) is a method for deciding several attributes. This method was designed with the initial aim of making it easier to apply the MAUT (Multi-Attribute Utility Theory) technique. This method has been developed over the years, based on identified failures, and has been improved to produce a method called SMARTS and the SMARTER method, which are presented in two different forms to correct the flaws of the MAUT method. In its implementation, the SMART method consists of seven stages

First, Determine the criteria used by using the research data to be used[23]. Second, give weight to each criterion by using the value between the minimum value to the maximum value desired with the most important priority. Third, normalize each weight which will compare the value of the criterion weight with the sum of the criterion weights, using the equation as below.

$$
W i=\frac{w^{\prime} i}{\sum_{j=1}^{m} \mathrm{~W}_{\mathrm{J}}}
$$

Where $\mathrm{Wi}$ is The criterion weight is normalized for the ith criterion value to i. $\mathrm{w}^{\prime}$ are weight for criterion $\mathrm{i}$, WJis weight for criterion $\mathrm{j}$., and $\mathrm{j}$ is the number of criteria $1,2 \ldots . \mathrm{m}$. Fourth, grading of these criteria can be in the form of quantitative data (numbers) or the form of qualitative data. If the criteria value is qualitative, it is necessary to change the criteria value to quantitative data by providing the criteria value parameter. Fifth, determine the utility value by converting the criteria value so that it becomes the criterion value in the form of standard data. The utility value generated depends on the nature of the criteria itself. as for the criteria used, namely the criteria for cost and profit criteria. Criteria for costs are "less value is more desirable value", for example, price criteria, product price criteria, and delivery time criteria can be calculated using the equation below.

$$
u_{i}\left(a_{i}\right)=\frac{\left(c_{\max }-c_{\text {out }}\right)}{\left(c_{\max }-c_{\min }\right)}
$$

Where $u_{i}\left(a_{i}\right)$ is the utility value of criterion $i$ for alternative i.c maxis maximum value of criteria. $c_{m i n}$ is the minimum value of criteria. $c_{\text {out }}$ is value criteria on i. and then, the profit criteria used for the benefit of being "a greater value is a more desirable value", for example, the criteria for room capacity criteria, product taste criteria, and others. To determine the utility value of this type using the equation below.

$$
u_{i}\left(a_{i}\right)=\frac{\left(c_{\text {out }}-c_{\min }\right)}{\left(c_{\max }-c_{\min }\right)}
$$

Where $u_{i}\left(a_{i}\right)$ is the utility value of criterion $\mathrm{i}$ for alternative i.c $c_{\max }$ is a maximum value of criteria. $c_{\min }$ is the 
minimum value of criteria. $c_{\text {out }}$ is value criteria on i. Sixth, determined from each criterion by multiplying the normalized value of the standard data criteria with the value of the normalized criterion weight. Then add up the value of the multiplication. the equation below.

$$
\begin{aligned}
& u\left(a_{i}\right) \\
& =\sum_{j=1}^{m} w_{j} \\
& \text { * } u_{j}\left(a_{i}\right)
\end{aligned}
$$

Where $\mathrm{u}\left(a_{i}\right)$ is the total score for each alternative to i. $w_{j}$ is the weight for criterion j. $u_{i}\left(a_{i}\right)$ is utility value from criterion to $\mathrm{j}$ for an alternative to $i$. Seventh, all the calculated values will produce the final score.

\section{RESULTS AND DISCUSSION}

\section{A. Analysis with the SMART method}

This study uses several parameters to determine a customer's decision in choosing product items as price, sell period, taste value. From the above parameters, the customer has determined a decision and can find the desired product using the SMART method. This research using 3 steps to analyze with the SMART method.

First, calculate the weight of the product using the criteria that have been determined by the researcher and will be normalized according to the product value.

Table1. Product Data Samples

\begin{tabular}{llll}
\hline \multirow{2}{*}{ Product } & \multicolumn{3}{c}{ Criteria } \\
\cline { 2 - 4 } & Price & Taste & Sell Period \\
\hline $\begin{array}{l}\text { Chocolate } \\
\text { bread }\end{array}$ & 3.000 & 5 & 362 \\
\hline $\begin{array}{l}\text { Cheese } \\
\text { Chocolate }\end{array}$ & 5.500 & 3 & 352 \\
\hline $\begin{array}{l}\text { Blueberry } \\
\text { Bread }\end{array}$ & 3.000 & 4 & 361 \\
\hline $\begin{array}{l}\text { Strawberry } \\
\text { Cream } \\
\text { Cheese }\end{array}$ & 5.500 & 4 & 267 \\
\hline $\begin{array}{l}\text { Sugar-apple } \\
\text { Bun }\end{array}$ & 3.500 & 3 & 308 \\
& & & \\
\hline
\end{tabular}

From the table above there are two normalization groupings used because the price criteria are better if the value is lower, while the taste and period criteria are better if the value is higher. The first normalization is the normalization of prices, assuming the price value is lower, the better, then in the process of normalizing product prices using the formula below:

$$
\frac{\left|x-x_{\max }\right|}{x_{\max }-x_{\min }}
$$

Where $\mathrm{x}$ is value. $x_{\max }$ is maximum value and $x_{\min }$ is the minimum value. The second normalization is the normalization of taste. The taste value and the selling period are the higher the better, then the normalization process uses the formula as above. the difference is that $x_{\max }$ and $x_{\min }$ are the maximum and minimum weight values for the standard taste. The third normalization is the normalization of the sale period. Then the normalization process uses the formula as above. the difference is that $x_{\max }$ and $x_{\min }$ are the maximum and minimum of the sale period. the results of the calculation of some normalization are as follows

Table2. Result of Normalization

\begin{tabular}{lccc}
\hline Product & Criteria & & \\
\cline { 2 - 4 } & Price & Taste & $\begin{array}{l}\text { Sell } \\
\text { Period }\end{array}$ \\
\hline Chocolate bread & 1 & 1 & 1 \\
\hline Cheese Chocolate & 0,852 & 0,5 & 0,969 \\
\hline Blueberry Bread & 1 & 0,75 & 0,996 \\
\hline $\begin{array}{l}\text { Cheese Cream } \\
\text { Strawberry }\end{array}$ & 0,852 & 0,75 & 0,705 \\
\hline Sugar-apple Bun & 0,970 & 0,5 & 0,832 \\
\hline
\end{tabular}

Second, in calculating this Relative Weight, the customer is required to provide a weight value for the criteria that have been determined by the researcher to produce a product selection decision that will be determined by the system by calculating the SMART method. In assessing the weight criteria, the customer can choose a weight value between 1 and 5, the weight value and will be calculated by the formula below: 


$$
\frac{x}{x_{\max }} X n
$$

Where $\mathrm{x}$ is the criterion weight value inputted by the customer. $x_{\max }$ is the maximum criterion weight value specified for the input customer. $\mathrm{n}$ is the value of the product criteria weight that has been normalized. In calculating the relative weight calculated using the formula above, a table like the one below will be produced

Table3. Relative Weight

\begin{tabular}{lccc}
\hline Product & Criteria & & \\
\cline { 2 - 4 } & Price & Taste & $\begin{array}{l}\text { Sell } \\
\text { Period }\end{array}$ \\
\hline Chocolate bread & 0,416 & 0,333 & 0,25 \\
\hline Cheese Chocolate & 0,355 & 0,166 & 0,242 \\
\hline Blueberry Bread & 0,416 & 0,249 & 0,249 \\
\hline $\begin{array}{l}\text { Cheese Cream } \\
\text { Strawberry }\end{array}$ & 0,35 & 0,249 & 0,176 \\
\hline Sugar-apple Bun & 0,404 & 0,166 & 0,208 \\
\hline
\end{tabular}

Third, then look for the ranking value or look for the highest value that will be suggested by the system for terminating product selection by adding up all the weighted criteria values that have been calculated by customer input.

$$
\begin{aligned}
\text { ranking value } & =\text { price }+ \text { taste } \\
& + \text { sale period }
\end{aligned}
$$

Then the results are added up from all the weighted values of the relative table criteria and will be sorted according to the ranking or highest to lowest value to get the results of decision making using the SMART method which will be shown in the results in table 4 .

Table 4. Result of Ranking Value

\begin{tabular}{lc}
\hline Product & Ranking period \\
\hline Chocolate bread & 0,999 \\
\hline Blueberry Bread & 0,914 \\
\hline Cheese Cream Strawberry & 0,779 \\
\hline Sugar-apple Bun & 0,777 \\
\hline Cheese Chocolate & 0,763 \\
\hline
\end{tabular}

\section{B. Implementation of SMART Methods in Mobile Applications}

2 application platforms will be used for ordering information applications. Namely based on android and website. Android is used by customers and the website is used by officers. Website is used to manage order data, prices, officers, and customers. this website is formed using the bootstrap style for the frontend and PHP for the backend.

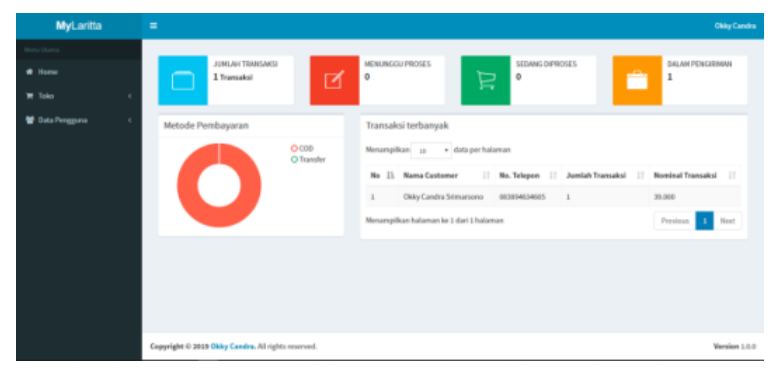

Figure 1. officer dashboard view based on web app

Applications that are used by Androidbased customers are designed for registration, application login, selecting products, transactions, checking orders, and rating orders that have been made

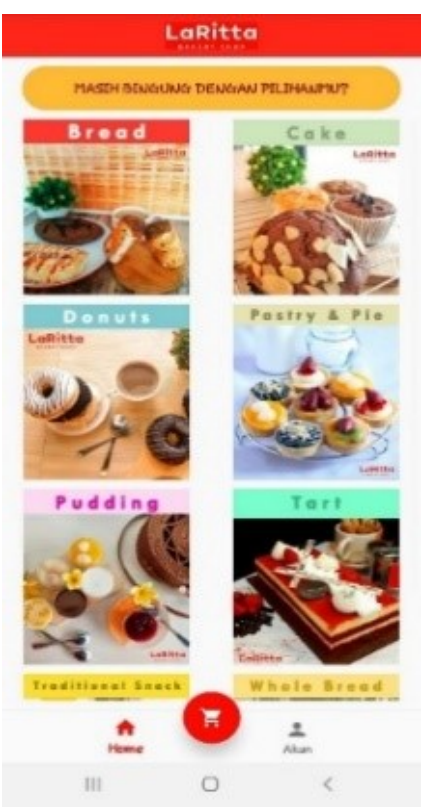

Figure 2. menu display user based on Android App

Besides that, customers can use the order selection feature using the SMART method which will later be useful for customers as a customer reference for choosing the appropriate food as in Figure 3.Before that, customers are advised to choose standard criteria to start as in Figure 4. 


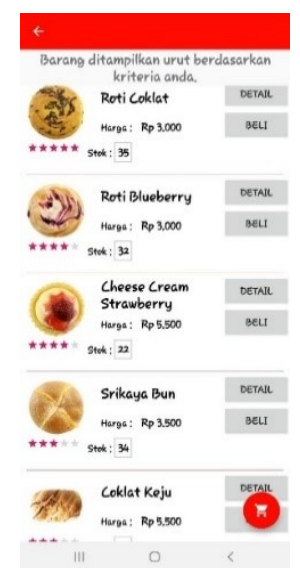

Figure 3. Result of SMART method

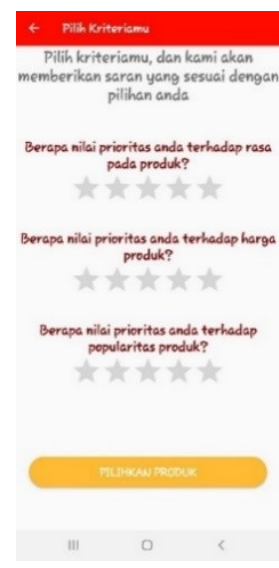

Figure 4. criteria selection form

\section{CONCLUSION}

In this study, it can be concluded that the SMART method can be used appropriately for the design of this Android-based bread ordering information system, and it can make it easier for customers to choose product items. Because in this bakery there are not only a few items but many items that are sold so that customers are confused about choosing the bread they want, with this SMART method the customer becomes easier to choose because several criteria have been given that is very suitable to be given a value and provide item results. products desired by customers.

For that, the customer will feel more attention in selecting the desired product in ordering bread, for the weight of the criteria there is input by the customer in the assessment. In this program, 3 criteria parameters are determined by the program, namely the taste value, the price value, and the selling period value.

\section{REFERENCES}

[1] A. Habib, M. A. Jani, D. A. Pratama, and E. Ronando, "Development of archives management information system with RFID and SMS gateway," International Journal of Psychosocial Rehabilitation, vol. 24, no. 4, pp. 52275243, 2020, DOI: 10.37200/IJPR/V24I4/PR201621.

[2] R. A. Santana, D. Risqiwati, and Z. Sari, "Rancang Bangun Sistem Informasi Servis Oli Sepeda Motor Menggunakan Odometer Berbasis LBS," Kinetik, vol. 2, no. 1, p. 17, 2017, doi: 10.22219/kinetik.v2i1.98.

[3] I. L. Andrey Kartika Widhy Hapantenda, Ardy Januantoro, "STUDI INDEPENDEN KOMPARASI SEGMENTASI SEL DARAH PUTIH MENGGUNAKAN RUANG WARNA HSV DENGAN CIE-L*a*b," Konvergensi, vol. 15, 2019.

[4] A. Habib and B. Al Kindhi, "Rancang Bangun Sistem Informasi Manajemen Keuangan Sekolah," INTENSIF: Jurnal Ilmiah Penelitian dan Penerapan Teknologi Sistem Informasi, vol. 2, no. 2, p. 136, 2018, doi: 10.29407/intensif.v2i2.12139.

[5] Yudhi and A. Rustam, "Perancangan Aplikasi Mobile Untuk Pemasaran Produk Dan Jasa Ke Berbagai Situs ECommerce Di Indonesia," Jurnal Informasi Volume VI No. 2/November/2014, vol. VI, no. 2, pp. 88-99, 2017.

[6] M. Siregar et al., "Rancang Bangun Aplikasi Berbasis Mobile Untuk Navigasi Ke Alamat Pelanggan Tv Berbayar (Studi Kasus: Indovision Cabang Pekanbaru) 1," Jurnal Rekayasa dan Manajemen Sistem Informasi, vol. 2, no. 1, pp. 82-94, 2016, [Online]. Available: www.hostinger.co.id. 
[7] A. Purwanto and A. Nugroho, "Analisis Rancangan Teknologi Mobile Application Pada E-Booking Ruangan Untuk Kegiatan Ukm," Jurnal Teknologi Informasi dan Komputer, vol. 4, no. 1, pp. 66-70, 2018, doi: 10.36002/jutik.v4i1.396.

[8] A. Habib and A. D. Wibowo, "Aplikasi Pengingat Agenda Berdasarkan Lokasi Dengan Global Positioning System (Gps) Berbasis Android," Konvergensi, vol. 11, no. 02, 2016, doi: 10.30996/konv.v12i01.862.

[9] S. Syaifuddin, Z. Sari, and M. K. Masduqi, "Analysis of Uapush Malware Infection using Static and Behavior Method on Android," Kinetik, vol. 3, no. 1, p. 83, 2018, doi: 10.22219/kinetik.v3i1.265.

[10] C. Kirana and R. Wahdaniyah, "Implementasi Aplikasi Alumni Berbasis Mobile Application," Jurnal Edukasi dan Penelitian Informatika (JEPIN), vol. 4, no. 2, p. 179, 2018, doi: $10.26418 /$ jp.v4i2.25752.

[11] D. Defrina and D. P. Lestari, "Aplikasi Pemesanan Makanan Dan Minuman Online Aplication of Ordering Food and Beverages Online Based on Mobile Browser on Tiga Saudara Restaurant," Jurnal Ilmiah Informatika dan Komputer, vol. 22 , no. 3, pp. 158-170, 2017, [Online]. Available: http://ejournal.gunadarma.ac.id/index.p hp/infokom/article/view/1736.

[12] L. Candra and A. A. Alkodri, "Aplikasi Pemesanan Makanan Pada Bangka Original Cafe Berbasis Client Server Dengan Platform Android," Jurnal Sisfokom (Sistem Informasi dan Komputer), vol. 3, no. 2, p. 34, 2014, doi: 10.32736/sisfokom.v3i2.205.

[13] I. Inayati, "Aplikasi Pemesanan Makanan Berbasis Web," eNARODROID, vol. 1, no. 2, 2015, doi: 10.31090/narodroid.v1i2.71.

[14] A. Izzah, "Prediksi Harga Saham Menggunakan Improved Multiple Linear Regression untuk Pencegahan Data Outlier," Kinetik, vol. 2, no. 3, pp.
141-149, 2017 ,

doi: 10.22219/kinetik.v2i3.268

[15] A. Suryadi, "Sistem Pendukung Keputusan Seleksi Ujian Masuk Perguruan Tinggi Menggunakan Nbc (Naïve Bayes Classifier)," Kinetik, vol. 1, no. 3, p. 173, 2016, doi: 10.22219/kinetik.v1i3.120.

[16] Nurhasanah, "Pendukung Keputusan Penentuan Penerima Beasiswa Menggunakan Metode Smart ( Simple Multi Attribute Rating Technique )," Majalah Ilmiah INTI, vol. XII, no. 1, pp. 60-66, 2017.

[17] Y. E. Windarto, I. P. Windasari, and M. A. M. Arrozi, "Implementasi Simple Multi Attribute Rating Technique Untuk Penentuan Tempat Pembuangan Akhir," Jurnal Pengembangan Rekayasa dan Teknologi, vol. 15, no. 1, p. $12, \quad 2019, \quad$ doi: 10.26623/jprt.v15i1.1484.

[18] E. Oktavianti, N. Komala, and F. Nugrahani, "Simple multi attribute rating technique (SMART) method on employee promotions," Journal of Physics: Conference Series, vol. 1193, no. 1, 2019, doi: 10.1088/17426596/1193/1/012028.

[19] M. Safrizal, "Sistem Pendukung Keputusan Pemilihan Karyawan Teladan dengan Metode SMART (Simple Multi Attribute Rating Technique)," Jurnal CoreIT, vol. 1, no. 2, pp. 25-29, 2015.

[20] D. diana, "Sistem Pendukung Keputusan Menentukan Kelayakan Bisnis Menerapkan Simple Multi Attribute Rating Technique (Smart), Jurnal Ilmiah Matrik, pp. 113-124, 2016 , doi: 10.33557/jurnalmatrik.v18i2.403.

[21] N. Sesnika, D. Andreswari, and R. Efendi, "Aplikasi Sistem Pendukung Keputusan Pemilihan Gedung Serba Guna Di Kota Bengkulu Dengan Menggunakan Metode Smart Berbasis Android," Jurnal Rekursif, vol. 4, no. 1, pp. 30-44, 2016. 
[22] J.-D. Huang, M. H. Hu, and H.-M. Wee, "Evaluation of Lead Logistics Provider Using the SMART Process: A Case Study in a Taiwan Automotive Industry," Operations and Supply Chain Management: An International Journal, vol. 6, no. 1, pp. 26-35, 2014, doi: $10.31387 / \mathrm{oscm} 0130084$

[23] S. R. Cholil, A. P. R. Pinem, and V. Vydia, "Implementasi metode Simple Multi Attribute Rating Technique untuk penentuan prioritas rehabilitasi dan rekonstruksi pascabencana alam," Register: Jurnal Ilmiah Teknologi Sistem Informasi, vol. 4, no. 1, p. 1, 2018, doi: 10.26594/register.v4i1.1133. 